\title{
Oogenesis pattern and type of ovariole of the parasitoid Palmistichus elaeisis (Hymenoptera: Eulophidae)
}

\author{
GILBERTO S. ANDRADE ${ }^{1}$, ADALBERTO H. SOUSA ${ }^{2}$, JULIANA C. SANTOS ${ }^{3}$, \\ FARAH C. GAMA ${ }^{4}$, JOSÉ E. SERRÃ ${ }^{5}$ and JOSÉ C. ZANUNCIO ${ }^{6}$ \\ ${ }^{1}$ Departamento de Agronomia, Universidade Federal de Rondônia, \\ Avenida Norte-Sul, 700, Bairro Nova Morada, 76940-000 Rolim de Moura, RO, Brasil \\ ${ }^{2}$ Centro de Ciências Biológicas e da Natureza, Universidade Federal do Acre, \\ Campus Distrito Industrial, 69915-000 Rio Branco, AC, Brasil \\ ${ }^{3}$ Departamento de Entomologia, Universidade Federal de Lavras, 37200-000 Lavras, MG, Brasil. \\ ${ }^{4}$ Empresa Brasileira de Pesquisa Agropecuária, Embrapa Semiárido, 56302-970 Petrolina, PE, Brasil \\ ${ }^{5}$ Departamento de Biologia Geral, Universidade Federal de Viçosa, Avenida PH Rolfs, s/n, \\ Campus Universitário, s/n, 36570-000 Viçosa, MG, Brasil \\ ${ }^{6}$ Bioagro, Universidade Federal de Viçosa, Avenida PH Rolfs, \\ Campus Universitário, 36570-000 Viçosa, MG, Brasil
}

Manuscript received on August 23, 2010; accepted for publication on April 5, 2011

\begin{abstract}
The knowledge on ovigeny in parasitoids is important for basic studies on physiology and applied biological control. The ovigeny pattern and type of ovariole of the parasitoid Palmistichus elaeisis Delvare \& LaSalle (Hymenoptera: Eulophidae) were studied in newly-emerged females at seven, 14, 24 and $48 \mathrm{~h}$ intervals after their emergence from Tenebrio molitor L. pupae (Coleoptera: Tenebrionidae). Females of P. elaeisis presented ovaries composed by four ovarioles of the meroistic polytrophic type. The yolk accumulation and chorionogenesis in P. elaeisis were concluded $24 \mathrm{~h}$ after the female emergence. The $48 \mathrm{~h}$-old females show a high quantity of egg ready for oviposition. These findings can help to improve the mass production of $P$. elaeisis and the augmentative biological control by using this natural enemy.
\end{abstract}

Key words: Biological control, morphology, natural enemies, ovigeny.

\section{INTRODUCTION}

Parasitoids are studied because of their importance in the biological control of pests and are used in the development of population models and interactions with their hosts in the field (Hassel 2000, Andrade et al. 2009, 2010a). Internal and external factors can influence the reproductive success and the strategy

Correspondence to: Gilberto Santos Andrade E-mail: gilbertoandrade1@yahoo.com.br used by parasitoids, which are the basic components that should be considered for using these biological control agents (Ozkan 2007, Spataro and Bernstein 2007, Santolamazza-Carbone et al. 2007). The parasitism behavior depends on field conditions, host availability and the numbers of mature eggs during the cycle of each species (Jervis et al. 2001). For this reason, reproductive strategies results in variations on the dynamics of egg production by parasitoids (Ellers et al. 2000, Giron et al. 2004). 
The family Eulophidae has natural enemies and is used in many cultures (Santos Junior et al. 2006, Mendel et al. 2007) to control pest populations (Leite et al. 2006, Doganlar and Mendel 2007). Palmistichus elaesisis Delvare \& LaSalle (Hymenoptera: Eulophidae) is a polyphagous endoparasitoid of pupae of Diatraea saccharalis Fabr. (Lepidoptera: Pyralidae), Anticarsia gemmatalis Hüebner (Lepidoptera: Noctuidae), Heliothis virescens Fabr. (Lepidoptera: Noctuidae), Spodoptera frugiperda (J.E. Smith) (Lepidoptera: Noctuidae), Thyrinteina arnobia (Stoll) (Lepidoptera: Geometridae) (Bittencourt and Berti Filho 2004, Pereira et al. 2008) and Tenebrio molitor L. (Coleoptera: Tenebrionidae) (Zanuncio et al. 2008). This ability of P. elaeisis to develop in different hosts may be related to immune suppression that occurs with these hosts after the oviposition of parasitoids possibly due to immunoregulatory substances present in the ovary of this parasitoid (Andrade et al. 2010b).

The female reproductive system of insects consists, in general, of a pair of ovaries, connected to a common oviduct by a pair of oviducts. Each ovary is composed by a series of ovarioles with a progressive development of oocytes, whose number is genetically determined and dependent on the species reproductive strategy (Klowden 2002). Each ovariole has two areas of oocyte maturation named germarium and vitellarium (Chapman 1998). The germarium contains stem line oogonias and prefollicular tissues. The oocytes are then produced by meiotic divisions surrounded by follicular cells involved in the yolk deposition and chorionogenesis (Chapman 1998). The deposition of nutritive substances in the oocyte is higher in the vitellarium (Klowden 2002, Lisboa et al. 2005).

Ovarioles of insects can be of panoistic or meroistic types (Davey 1985, Nijhout 1994, Chapman 1998). The first one is found in more primitive insects and the germarium usually contains only oogonias, primary oocytes and mesodermal prefollicular tissue. The meroistic ovary has structures named nurse cells (Klowden 2002). The ovaries can, also, be subdivided in teleotrophic and polytrophic types (Nijhout 1994, Chapman 1998).

The nurse cells of the meroistic teleotrophic ovariole are found in the apex of the ovariole and are responsible for nurturing the oocytes by the nutritive cord. The ovocytes form a group of cells interconnected to the nurse ones in the meroistic polytrophic ovariole (Chapman 1998).

The yolk accumulation occurs by two patterns. In the first one, the mature eggs are formed in the late larval or pupal stage and in the second the maturation of eggs occurs along the adult stage of the insect (Jervis et al. 2001).

The knowledge on the sexual maturation of female parasitoids is a prerequisite to improve the mass rearing of this natural enemy. Thus, the efficiency of the parasitism of $P$. elaeisis in pupae of Bombyx mori L. (Lepidoptera: Bombycidae) occurred at 72 and $96 \mathrm{~h}$ (Pereira et al. 2009). This may be related to the oogeny of this natural enemy. Thus, the aims of this paper were to study the oogenesis pattern and the type of ovariole of $P$. elaeisis.

\section{MATERIALS AND METHODS}

Palmistichus elaeisis and their alternative host (T. molitor pupae) were reared in the laboratory at $25 \pm 1{ }^{\circ} \mathrm{C}$, relative humidity of $70 \pm 10 \%$, and photophase: $14 \mathrm{~h}$ (Zanuncio et al. 2008).

Tenebrio molitor was reared on plastic trays $(29 \times 23 \times 11 \mathrm{~cm})$ with integral wheat flour (97\%), beer yeast (3\%) and slices of chayote as food and humidity source.

Four 72 h-old females of $P$. elaeisis received T. molitor pupae during $24 \mathrm{~h}$ in glass tubes (14.0 $\times 2.2 \mathrm{~cm}$ ) covered with cotton and fed on honey (Zanuncio et al. 2008). Unmated females of this parasitoid were sexed by the morphologic characteristics of the antenna and abdomen (Delvare and LaSalle 1993) and individualized 
soon after their emergence from T. molitor pupae. The Zamboni fixative solution was utilized (Stefanini et al. 1967) to preserve newly-emerged females and at seven, 14, 24 and $48 \mathrm{~h}$ after their emergence.

The abdomens of six females of this insect were isolated per treatment, dehydrated in a graded ethanol series $\left(70,80,90\right.$ and $\left.95^{\circ}\right)$ and embedded in a historesin (Leica). Twelve $4 \mu \mathrm{m}$ thickness sections per treatment were stained with hematoxyline and eosin and analyzed under light microscope. The mature eggs were characterized by the presence of chorion and absence of nurse cells (Chapman 1998).

\section{RESULTS}

The ovaries of all females of $P$. elaeisis under analysis were similar to those of other Hymenoptera with a pair of ovaries with four ovarioles/ovary. These ovarioles joined and formed a calyx that opens in the lateral oviducts (Fig. 1).

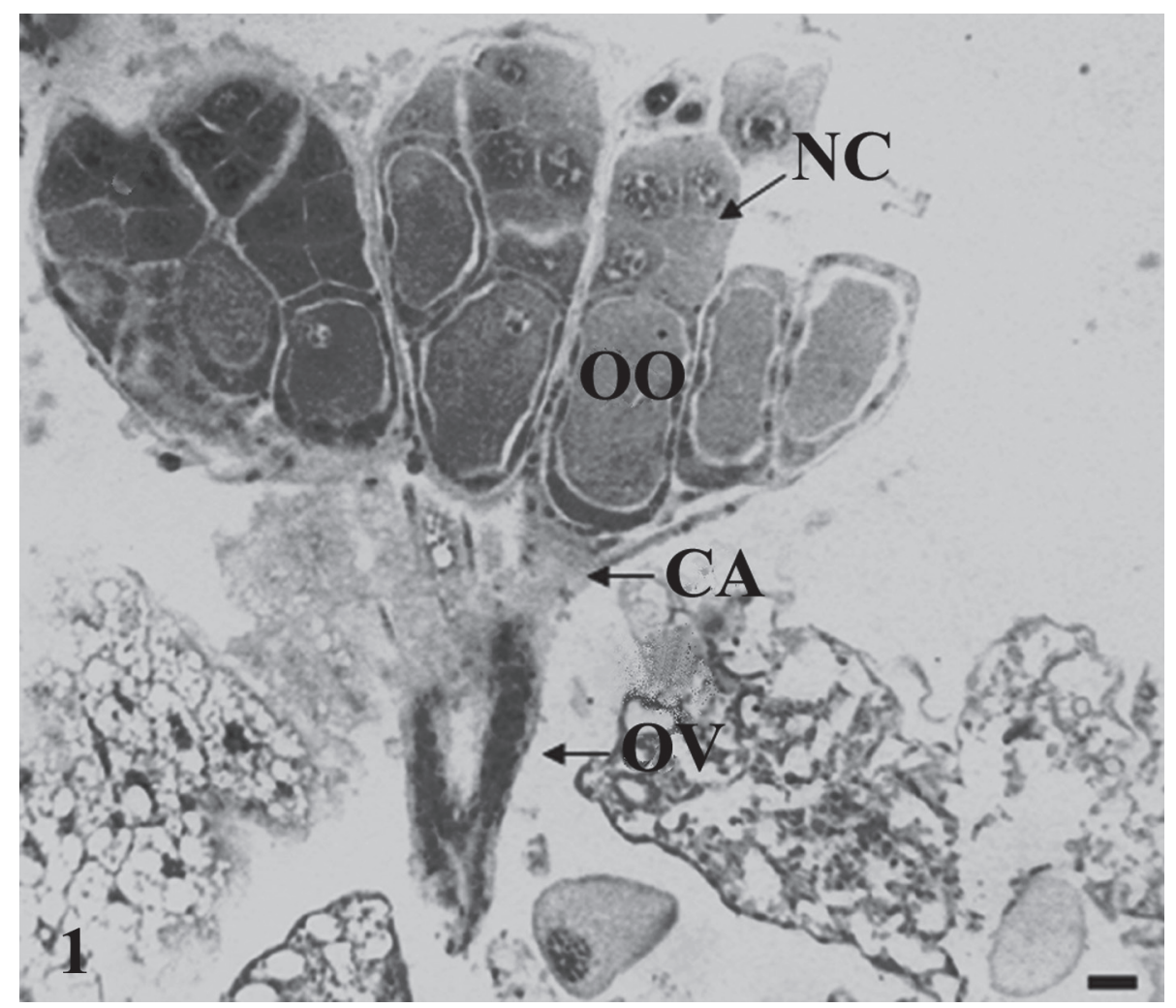

Figure 1 - Ovary of a newly-emerged females of Palmistichus elaeisis (Hymenoptera: Eulophidae) from Tenebrio molitor (Coleoptera: Tenebrionidae) pupae: OO- oocyte, NC- nurse cell CA- calyx, OV- lateral oviduct. Bar: $10 \mu \mathrm{m}$.

Palmistichus elaeisis presented an ovary of the meroistic polytrophic type due to its nurse cells being associated to the oocytes (Fig. 2). The nurse cells have well-developed nuclei (Fig. 3).

Newly-emerged females of $P$. elaeisis presented primary oocytes with the deposition of yolk and chorionogenesis, which was concluded
$24 \mathrm{~h}$ after the female emergence (Fig. 4). Besides, the high quantity of eggs ready to oviposition occurred at 48 h-old females (Fig. 5). Females did not show matured eggs until 24 hours after emergence. The mean number of matured eggs by female was $22.00 \pm 6.75$ and $72.17 \pm 14.23$ in 24 and $48 \mathrm{~h}$-old ones, respectively. 


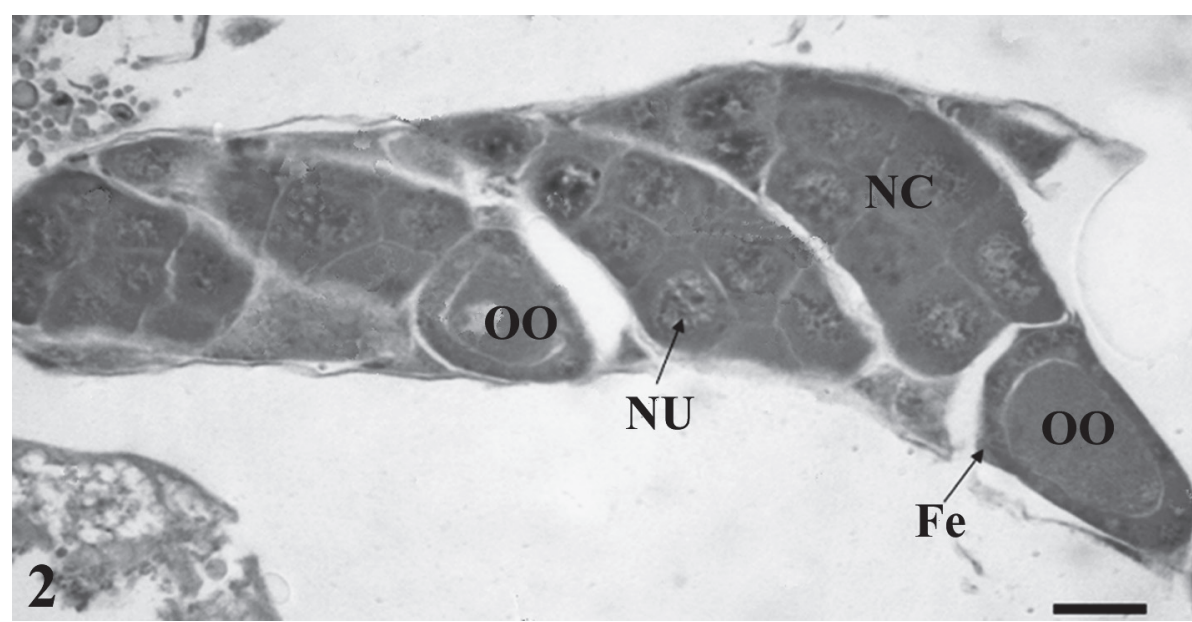

Figure 2 - Follicle (oocyte + nurse cells) of a newly-emerged females of Palmistichus elaeisis (Hymenoptera: Eulophidae). OO- oocyte, NU- nucleus of the nurse cells, NC- nurse cells, $\mathrm{Fe}-$ follicular epithelium. Bar: $10 \mu \mathrm{m}$.

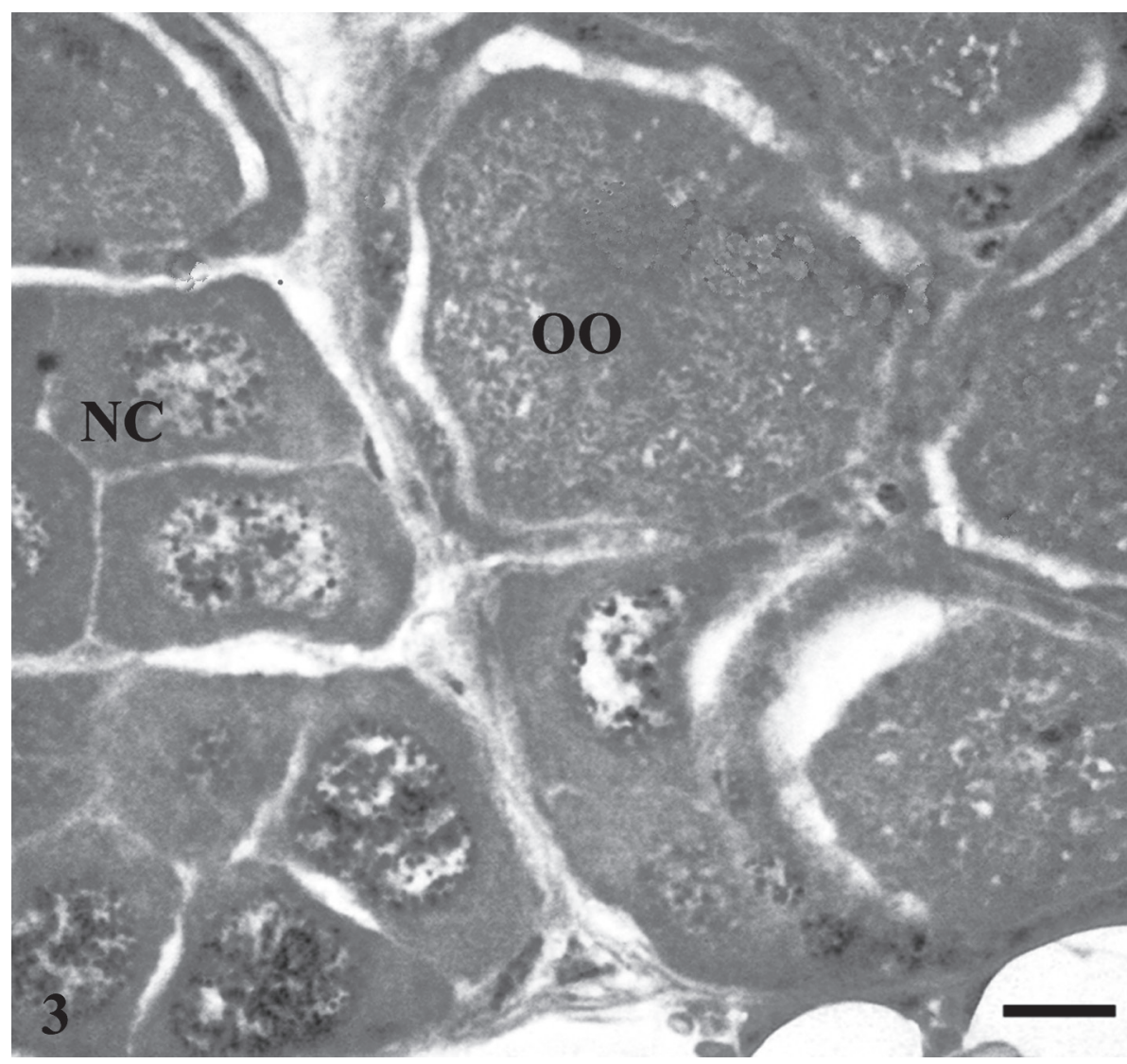

Figure 3 - Yolk accumulation in the oocytes (OO) of females of Palmistichus elaeisis (Hymenoptera: Eulophidae) after seven hours of their emergence from Tenebrio molitor (Coleoptera: Tenebrionidae) pupae. $\mathrm{NC}-$ nurse cells. Bar: $10 \mu \mathrm{m}$. 


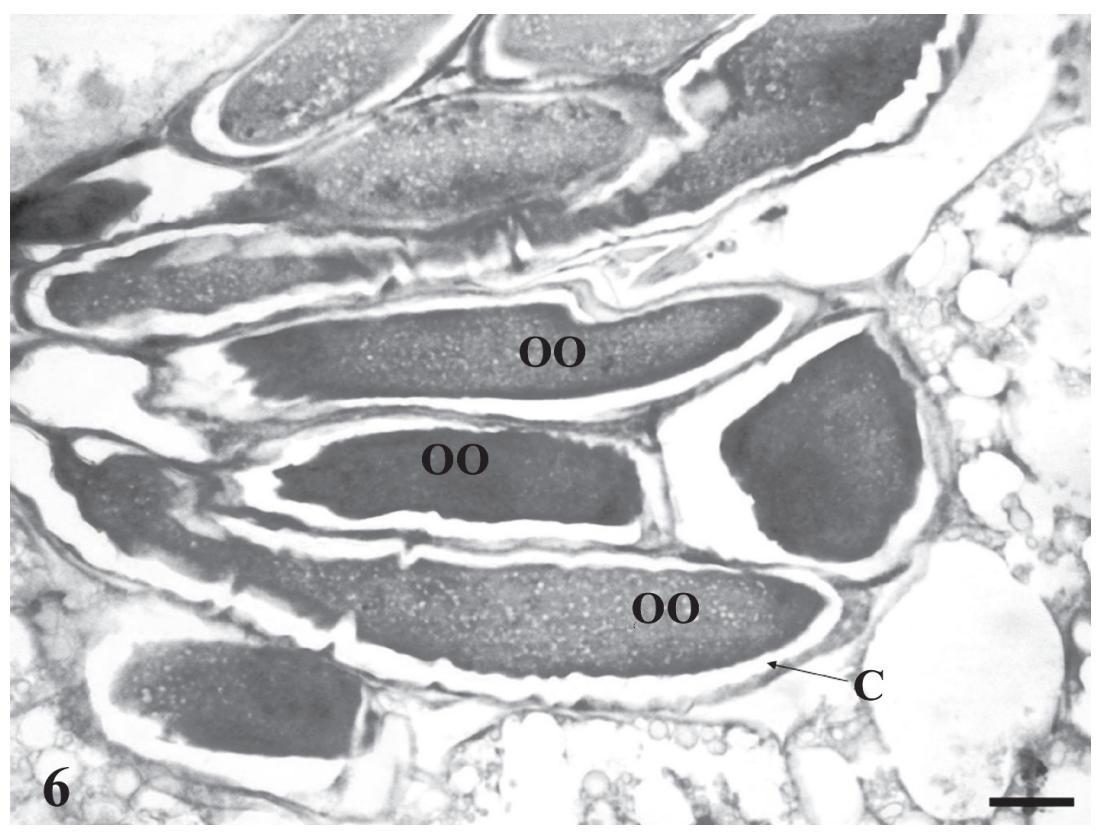

Figure 4 - Mature oocytes (OO) of females of Palmistichus elaeisis (Hymenoptera: Eulophidae) $24 \mathrm{~h}$ after their emergence from Tenebrio molitor (Coleoptera: Tenebrionidae) pupae. C- chorion. Bar: 10 $\mu \mathrm{m}$.

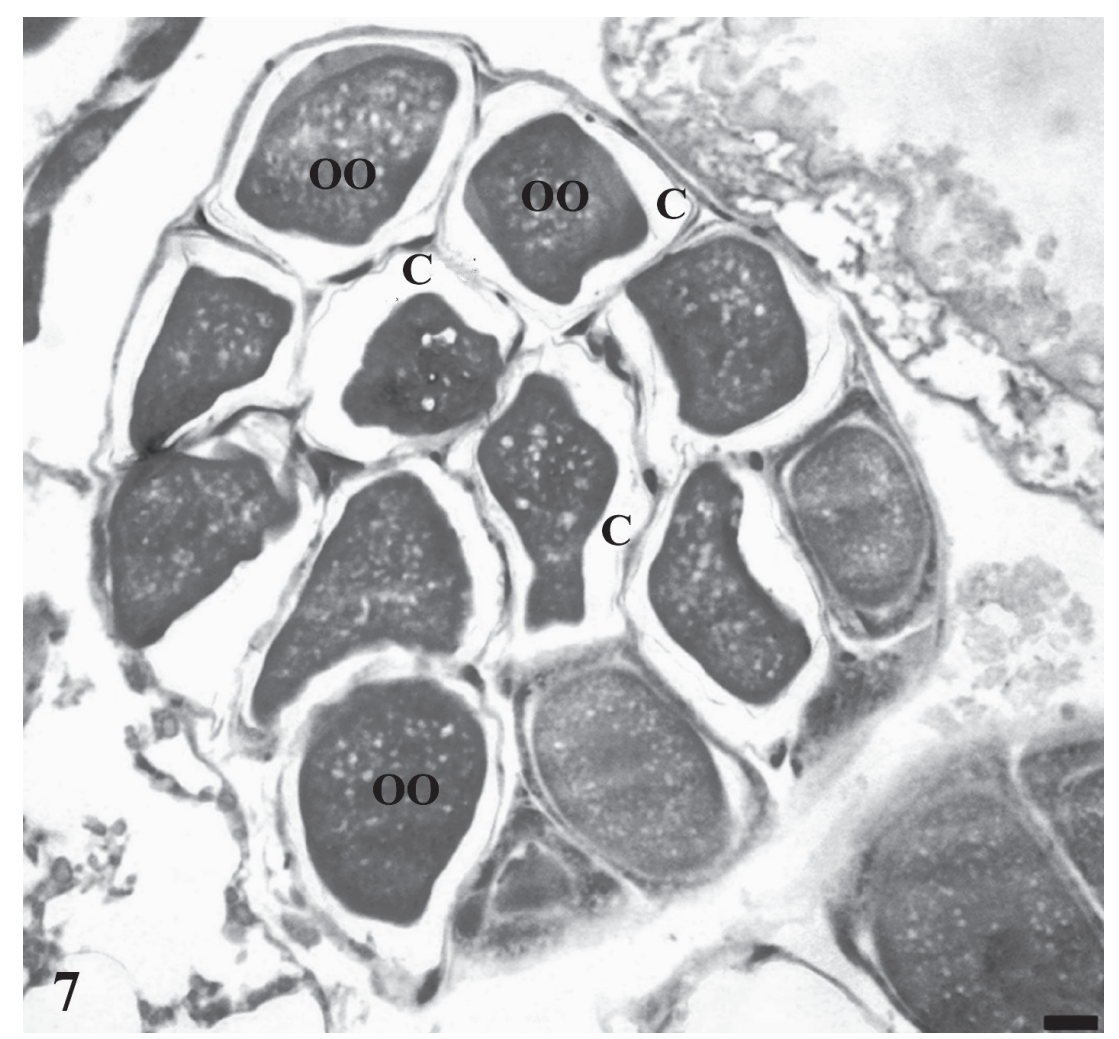

Figure 5 - Mature oocytes (OO) of females of Palmistichus elaeisis (Hymenoptera: Eulophidae) $48 \mathrm{~h}$ after their emergence from Tenebrio molitor (Coleoptera: Tenebrionidae) pupae. C- chorion. Bar: 10 $\mu \mathrm{m}$. 


\section{DISCUSSION}

The number of ovarioles per ovary is speciesspecific and varies from one (in some coleopterans) to more than thousands (in termites) (Nijhout 1994) depending on the size, life history and taxonomic position of the insect (Chapman 1998). However, intra-specific differences for the number of ovarioles in insects can occur due to genetic and stressing factors as starvation, and the largest number of ovarioles has no positive correlation with the fecundity of Drosophila melanogaster (Meigen) (Diptera: Drosophilidae) (Wayne et al. 2006). The oogenesis of females of $P$. elaeisis, as demonstrated after the emergence, is similar to that of reports on egg maturation of many Hymenoptera species (Jervis et al. 2001, Martins and Serrão 2004). The gradual oocyte growth associated with the increase of $P$. elaesis age is related to the yolk accumulation of this insect with a pattern similar to most Hymenoptera species (Jervis et al. 2001). The number of mature eggs in newly-emerged parasitoids allows them to produce a great number of eggs/oviposition, but the reduction of the host availability decreases the parasitism rate (Jervis et al. 2001, Jervis and Ferns 2004). On the other hand, the low proportion of mature eggs is a disadvantage because only a small fraction of the life period of parasitoids is used for egg production, but it gives a larger reproductive plasticity for variations on host availability (Ellers and Jervis 2003, Jervis and Ferns 2004). Synovigenic species have yolk-rich eggs. This suggests the presence of a great amount of fat body, low ovigeny index, relatively long life time, gradual increase until the stabilization of the oviposition and feeding behavior of P. elaeisis (Jervis et al. 2001).

The gradual development of the oocytes after their emergence in insects was associated with a high number of fat body cells, which are the main cells responsible for the vitellogenin synthesis (Palli and Locke 2008), which is the case of females of $P$. elaeisis. Females of $P$. elaeisis starved for $72 \mathrm{~h}$ present high parasitism. This indicates that the metabolic reserves may be used for egg production without compromising their development during the period evaluated (Ueno and Ueno 2007, Ozkan 2007). However, the maturation by endogenous regulation can be retarded when the host has low nutrient quality or quantity or when it offers that they offer low energy for the parasitism of synovigenic insects (Desouhant et al. 2005, Wu and Heimpel 2007). On the other hand, food sources cannot influence the egg maturation of parasitoids (Sisterson and Averill 2002).

The complete development of oocytes of $P$. elaeisis was observed in $24 \mathrm{~h}$-old females and, as for other species, the yolk deposition in the oocytes occurred in the proximal area of the ovariole (Klowden 2002). The death of follicular cells after the complete synthesis of the chorion results in the inhibition of the transport of substances to the oocyte (Klowden 2002, Martins and Serrão 2004).

One possible response to the higher reproductive success of $P$. elaesis aged between 72 and $96 \mathrm{~h}$ compared with younger individuals in $B$. mori (Pereira et al. 2009) is the maturation of oocytes occurring throughout the adult life of the parasitoid with a high concentration of eggs after $48 \mathrm{~h}$, as demonstrated in this study. Thus, these findings may help to improve the mass production of P. elaeisis, understand some characteristics of the reproductive physiology of Eulophidae and predict the release time to improve the efficiency of $P$. elaeisis.

\section{ACKNOWLEDGMENTS}

To "Coordenação de Aperfeiçoamento de Pessoal de Nível Superior (CAPES)", "Fundação de Amparo à Pesquisa do Estado de Minas Gerais (FAPEMIG)" and "Conselho Nacional de Desenvolvimento Científico e Tecnológico (CNPq)".

\section{RESUMO}

O conhecimento da ovigenia em parasitóides é importante para estudos básicos em fisiologia e para o controle biológico aplicado. O padrão de ovigenia e 
o tipo de ovaríolo do parasitóide Palmistichus elaeisis Delvare \& LaSalle (Hymenopera: Eulophidae) foram estudados em fêmeas recém-emergidas e em intervalos de sete, 14, 24 de 48 horas após a emergência em pupas de Tenebrio molitor L. (Coleoptera: Tenebrionidae). Fêmeas de $P$. elaesis apresentaram o ovário composto por quatro ovaríolos do tipo meroístico politrófico. A deposição de vitelo e corionogênese em $P$. elaeisis foram concluídas 24 horas após a emergência. Fêmeas com 48 horas de idade apresentam grande quantidade de ovos prontos para a oviposição. Esses resultados podem ajudar a melhoria da produção massal de P. elaeisis e o controle biológico aplicado com esse parasitóide.

Palavras-chave: Controle biológico, morfologia, inimigo natural, ovigenia.

\section{REFERENCES}

Andrade GS, Pratissoli D, Barros R, Zago HB, Pereira AIA AND DALVI LP. 2010a. Screening of two Trichogramma species, native to southeastern Brazil, for the control of tobacco budworm. Rev Colomb Entomol 36: 16-19.

Andrade GS, Pratissoli D, Torres JB, Barros R, DAlvi LP AND ZAGO HB. 2009. Parasitismo de ovos de Heliothis virescens por Trichogramma spp. pode ser afetado por cultivares de algodão. Acta Sci Agron 31: 569-573.

ANDRADE GS, SERRÃo JE, ZANUNCIO JC, ZANUNCIO TV, LEITE GLD AND POLANCZYK RA. 2010b. Immunity of an alternative host can be overcome by higher densities of its parasitoids Palmistichus elaeisis and Trichospilus diatraeae. Plos One 5: e13231.

Bittencourt MAL And Berti Filho E. 2004. Desenvolvimento dos estágios imaturos de Palmistichus elaeisis Delvare e Lasalle (Hymenoptera, Eulophidae) em pupas de Lepidoptera. Rev Bras Entomol 48: 65-68.

CHAPMAN RF. 1998. The insects: structure and function, $4^{\text {th }}$ ed., Cambridge: Cambridge University Press, 770 p.

DAVEY KG. 1985. The female reproductive tract. In: KERKUT GA AND GILBERT LI (Eds), Comprehensive Insect Physiology, Biochemistry and Pharmacology Oxford: Pergamon Press, p. 15-36.

Delvare G AND Lasalle J. 1993. A new genus of Tetrastichinae (Hymenoptera: Eulophidae) from the Neotropical region, with a description of a new species parasitic on key pests of oil palm. J Nat Hist 27: 435-444.

Desouhant E, Driessen G, Amat I and Bernstein C. 2005. Host and food searching in a parasitic wasp Venturia canescens: a trade-off between current and future reproduction? Anim Behav 70: 145-152.
Doganlar M AND Mendel Z. 2007. First record of the eucalyptus gall wasp Ophelimus maskelli and its parasitoid, Closterocerus chamaeleon, in Turkey. Phytoparasitiva 35: 333-335.

ELLERS J AND JERVIS MA. 2003. Body size and the timing of egg production in parasitoid wasps. Oikos 102: 164-172.

Ellers J, SEvenster JG AND Driessen G. 2000. Egg load evolution in parasitoids. Am Nat 156: 650-665.

GIRON D, PINCEBOURDE S AND CASAS J. 2004. Lifetime gains of host-feeding in a synovigenic parasitic wasp. Physiol Entomol 29: 436-442.

HASSELl MP. 2000. Host-parasitoid dynamics. J Anim Ecol 69: 543-566.

JeRVIS MA AND FERnS PN. 2004. The timing of egg maturation in insects: ovigeny index and initial egg load as measures of fitness and of resource allocation. Oikos 107: 449-460.

Jervis MA, HeIMPEl GE, FERns PN, HARVEy JA AND KIDD NAC. 2001. Life-history strategies in parasitoid wasps: a comparative analysis of 'ovigeny'. J Anim Ecol 70: 442-458.

KLOWDEN MJ. 2002. Physiological systems in insects. New York: Academic Press, 448 p.

Leite GLD, PiCANÇO M, ZANUNCIO JC AND ECOlE CC. 2006. Factors affecting herbivory of Thrips palmi (Thysanoptera: Thripidae) and Aphis gossypii (Homoptera: Aphididae) on the eggplant (Solanum melongena). Braz Arch Biol Techn 49: 361-369.

Lisboa LCO, Serrão Je, Cruz-Landim C And Campos LAO. 2005. Effect of larval food amount on ovariole development in queens of Trigona spinipes (Hymenoptera: Apinae). Anatomia, Histologia, Embriyolia 34: 179-184.

Martins GF AND SERRÃo JE. 2004. Changes in the reproductive tract of Melipona quadrifasciata anthidioides (Hymenoptera: Apidae: Meliponini) queen after mating. Sociobiology 44: 241-254.

Mendel Z, Protasov A, Blumberg D, Brand D, SAPhir N, MADAR Z AND LA SALLE J. 2007. Release and recovery of parasitoids of the eucalyptus gall wasp Ophelimus maskelli in Israel. Phytoparasitica 35: 330-332.

NiJHOUT HF. 1994. Reproduction. In: NIJHOUT HF (Ed), Insect Hormone. Princeton University, Princeton, p. 142-159.

OZKAN C. 2007. Effect of food, light and host instar on the egg load of the synovigenic endoparasitoid Venturia canescens (Hymenoptera: Ichneumonidae). J Pest Sci 80: 79-83.

PALLI SR AND LOCKE M. 2008. The synthesis of hemolymph proteins by the larval fat body of an insect Calpodes ethlius (Lepidoptera: Hesperiidae). Insect Biochem 18: 405-413.

Pereira FF, Zanuncio TV, Zanuncio JC, Pratissoli D AND TAVARES MT. 2008. Species of lepidoptera defoliators of eucalyptus as new host for the parasitoid Palmistichus elaeisis (Hymenoptera: Eulophidae). Braz Arch Biol Techn 51: 259-262.

Pereira FF, Zanuncio TV, ZANuncio JC, SERrão JE, Oliveira HN, FÁvero K AND Grance E. 2009. Progênie de Palmistichus elaeisis Delvare \& LaSalle (Hymenoptera: Eulophidae) parasitando pupas de Bombyx mori L. (Lepidoptera: Bombycidae) de diferentes idades. Neotrop Entomol 38: 660-664. 
SANTOLAMAZZA-CARBONE S, NIETO MP AND RIVERA AC. 2007. Maternal size and age affect offspring sex ratio in the solitary egg parasitoid Anaphes nitens. Entomol Exp Appl 125: 23-32.

SANTOS JUNIOR HJG, MARQUES EJ, BARROS R AND GONDIM JR MGC. 2006. Interação de Metarhizium anisopliae (Metsch.) Sorok., Beauveria bassiana (Bals.) Vuill. e o parasitóide Oomyzus sokolowskii (Kurdjumov) (Hymenoptera: Eulophidae) sobre larvas da traça-das-crucíferas, Plutella xylostella (L.) (Lepidoptera: Plutellidae). Neotrop Entomol 35: 241-245.

Sisterson MS AND AVERILL AL. 2002. Costs and benefits of food foraging for a braconid parasitoid. J Insect Behav 15: 571-588.

SPATARO T AND BERNSTEIN C. 2007. Influence of environmental conditions on patch exploitation strategies of parasitoids. Behav Ecol 18: 742-749.
Stefanini M, DEMARTINO C AND ZAMBONI L. 1967. Fixation of ejaculated spermatozoa for electron microscopy. Nature 216: 173-174.

UEnO T AND UENO K. 2007. The effects of host-feeding on synovigenic egg development in an endoparasitic wasp, Itoplectis naranyae. J Insect Sci 46: 1-13.

WAYNE ML, Soundararajan U AND HARSHMAN LG. 2006. Environmental stress and reproduction in Drosophila melanogaster: starvation resistance, ovariole numbers and early age egg production. BMC Evol Biol 6: art. n. 57.

Wu Z AND HeIMPEL GE. 2007. Dynamic egg maturation strategies in an aphid parasitoid. Physiol Entomol 32: 143-149.

Zanuncio JC, Pereira FF, Jacques GC, TAVARES MT AND SERRÃo JE. 2008. Tenebrio molitor Delvare \& LaSalle (Coleoptera: Tenebrionidae), a new alternative host to rear the pupae parasitoid Palmistichus elaeisis (Hymenoptera: Eulophidae). Coleopt Bull 63: 32-38. 